\title{
An Analysis of the LPCs' Returns in the Middle East Markets: The Search for the Efficient Frontier
}

\author{
Anas Al Bakri ${ }^{1}$ \\ ${ }^{1}$ Department of Management and Marketing, College of Business and Economics, Qatar University, Qatar \\ Correspondence: Anas Al Bakri, Department of Management and Marketing, College of Business and \\ Economics, Qatar University, Doha, P.O.BOX 2713, Qatar. Tel: 974-4403-5047. E-mail: anasbakri@qu.edu.qa
}

Received: October 18, 2013

Accepted: November 11, $2013 \quad$ Online Published: November 26, 2013

doi:10.5539/ijef.v5n12p183

URL: http://dx.doi.org/10.5539/ijef.v5n12p183

\begin{abstract}
This paper analysed the performance of selected property companies (PCs) stocks returns observed over the time period from Jan 2007 to June 2012. The analysis is based on the Markowitz Model and the Single Index Model (SIM). This paper focused on the results from the Markowitz Model in particular, as the SIM is a simplified approach. The selection of the assets for either portfolio was exhaustive relying on various reputable data sources reporting financial characteristics of each stock. The specific criteria for selecting an asset in all portfolios are volume, $\mathrm{P} / \mathrm{E}$ ratio, return on equity, positive returns and data sufficiency. Thus, the current study considered PCs stocks with large trading volume to avoid daily swings in security prices. The study compared the return on equity (ROE) of each stock with the ROE of its real estate sector, selecting only those stocks that historically outperformed the sector. PCs with unusually high P/E ratios and those with missing P/E data were excluded. Monthly returns were used for the calculations. The analysis of the results clearly indicated the significance of selecting an appropriate time span for the historical stocks returns used for calculating the efficient frontier. It was shown in this paper that the estimated parameters of the models differ considerably when different time frames are chosen for the analysis. In addition the number of observations used for the calculations has great ramifications on the accuracy of the estimates. As long time spans do not reflect the current character of stocks it becomes important to keep the intervals between observations as narrow as possible. The efficient frontiers for both models were analysed and justifications for the inclusion and exclusion of certain stocks were discussed. Certainly, it is important to note that the outcome of this paper is specific to the PCs stocks that were included in each portfolio and during the period in which this paper was conducted. Also this study concluded that as Real Estate market becomes more volatile, such results may not hold due to greater imbalances and global market inefficiency.
\end{abstract}

Keywords: efficient frontier, property companies, Markowitz model, Single Index model, portfolio, real estate market

\section{Introduction}

\subsection{The Objective of the Study}

The main purpose of this paper is to analyse the performance of selected property companies (PCs) stocks returns observed over the time period from Jan 2007 to June 2012. The analysis is based on the Markowitz Model and the Single Index Model (SIM). The Markowitz Model and the SIM are factor models that can be used to predict portfolio volatility and expected returns. The Markowitz model, which was introduced in 1952, allows investors to calculate the single combination of securities from a given population that offer the lowest volatility of returns over the preceding period. The model shows a simple geometric graph of the trade-off between risk and return, the frontier itself is a composition of many portfolios; more specifically the efficient portfolios are a subset of minimum variance portfolios offering the highest return for each level of risk (Frino et al., 2001). The Single Index Model was introduced by Sharpe in 1963 which replaced the exact but cumbersome Markowitz formula for portfolio volatility with a simplified approximation that assumed that all the interrelationships among securities returns could be attributed to the fact that they respond differently to the pull of a single factor, which are the returns to the market itself. The aim of applying these models to the selected PCs stocks is to find efficient portfolios of shares. An efficient set is defined as a group of portfolios for which a higher return cannot be obtained for the same variance, or a lower variance is not possible for the same return (Marashdeh, 2007). The 
investment opportunity set has a minimum variance, which is a group of portfolios that have the lowest possible variance achievable for the population of property stocks, given their expected rates of return. Finding the efficient frontier allows for minimizing risk given a certain required expected rate of return.

This paper focuses on the results from the Markowitz Model in particular, as the SIM is a simplified approach. The SIM assumes that stocks returns are correlated for one reason only, which is that stocks respond to the pull of a single force, usually the market portfolio (Lintner, 1965). This implies that as the market moves in a certain direction stocks will follow it. However, this simplified analysis has its drawbacks. When using this model the actual variances of portfolios are not calculated, but only estimated. Due to the limitations of the SIM this study laid more emphasis on the Markowitz model.

\section{Method}

\subsection{Data and Selection Criteria}

The data consist of a selection of the Middle Eastern PCs stocks observed over time period from Jan 2007 to June 2012. The selection of the assets for either portfolio was exhaustive relying on various reputable data sources reporting financial characteristics of each stock. The specific criteria for selecting an asset in all portfolios are volume, $\mathrm{P} / \mathrm{E}$ ratio, return on equity, positive returns and data sufficiency. Thus, this research considered PCs stocks with large trading volume to avoid daily swings in security prices. We compared the return on equity (ROE) of each stock with the ROE of its real estate sector, selecting only those stocks that historically outperformed the sector. PCs with unusually high P/E ratios and those with missing P/E data were excluded. Monthly returns were used for the calculations. However, in order not to encompass the weekly data, the monthly observations were derived be averaging the weekly prices before calculating the monthly returns. The average is arguably a better representation of the month's prices than randomly selecting one observation that would represent the month. Table 1 shows the selected PCs in this study, which includes PC name, used symbol, country and stock markets names.

Table 1. Selected PCs from Middle East property markets

\begin{tabular}{lllll}
\hline Name & Symbol & Country & Industry & Stock Exchange \\
\hline Saudi Real Estate & SRECO & KSA & Real Estate & (KSA) Tadawul Stock Ex \\
Emaar Properties & EMAR & UAE & Real Estate & Dubai Stock Ex \\
Deyaar Development & DEYR & UAE & Real Estate & Dubai Stock Ex \\
Sorouh Real Estate & SOROUH & UAE & Real Estate & Abu Dhabi Securities Ex \\
Kuwait Real Estate & KRE & Kuwait & Real Estate & Kuwait Stock Ex \\
$\begin{array}{l}\text { Abyaar Real Estate Development } \\
\text { Barwa Real Estate }\end{array}$ & ABYAAR & Kuwait & Real Estate & Kuwait Stock Ex \\
Qatar Real Estate Investment & BRES & Qatar & Real Estate & Doha Securities Market \\
Arab Real Estate Development & ARED & Jordan & Real Estate & Amman Stock Exchange \\
Egyptian Real Estate Group & AREG & Egypt & Real Estate & Cairo \& Alexandria Stock Ex \\
\hline
\end{tabular}

Source: Developed for this Study, Arabian Business (2012); MCSI (2011); Local Stock Exchange Markets (2012).

Based on Markowitz's work, and in the context of domestic market, Sharpe (1964), Lintner (1965) and Mosin (1966) independently develop one of the most famous financial equilibrium models, the Capital Asset Pricing Model, which is referred to as the CAPM. In their model they assume that markets are segmented. The development of this model played a very important role in establishing the foundation of the modern portfolio theory. Errunza et al, (1992) mentioned that CAPM is an equilibrium economic model for valuing stocks by relating risk and expected return. It provides a precise prediction on this relationship (Errunza et al, 1985; Errunza et al., 1992). The model is graphically represented by the capital market line and Single Index Model which is implied by the following relationship:

$$
\left.\mathrm{E}\left(r_{i}\right)=r_{f}+\beta_{i} \mid \mathrm{E}\left(r_{m}\right)-r_{f}\right\rfloor
$$

Where $\mathrm{E}\left(r_{i}\right)$ and $\mathrm{E}\left(r_{m}\right)$ denote the expected return on security $i$ and the market portfolio, $r_{f}$ is the return on risk- 
free security and $\beta_{i}$ (beta) measures the sensitivity of security $i$ to the market risk factor- the slope of the line-, and it is quantified by:

$$
\beta=\frac{\operatorname{cov}\left(r_{m}, r_{i}\right)}{\operatorname{var}\left(r_{m}\right)}
$$

Where $\operatorname{cov}\left(r_{m}, r_{i}\right)$ is the covariance of returns of the $i$ th asset with the market $\operatorname{var}\left(r_{m}\right)$ is the total risk of the $i$ th asset. This total risk can be partitioned into two parts by using ordinary least squares as follow:

$$
\operatorname{var}\left(R_{i}\right)=\beta_{i}^{2} \operatorname{var}\left(R_{m}\right)+\operatorname{var}(e)
$$

Where $\beta_{i}^{2} \operatorname{var}\left(R_{m}\right)$ is the market risk (systematic risk) or the diversifiable risk, which is the portion of an asset's risk that cannot be eliminated via diversification? This risk indicates how including a particular asset in a diversified portfolio will contribute to the riskiness of the portfolio, in other words this sort of risk relates to general market movements. $\operatorname{var}(e)$ is the firm- specific risk or (unsystematic risk) that can be diversified or eliminated away (cancel out) by including the security as part of diversifiable portfolio (Marashdeh, 2007). According to the Cho et al., (1986); Mittoo, Usha (1992), when using CAPM framework, the stock returns follow a SIM and multi-factor model:

$$
R_{i t}^{J}=E_{i t}+\sum_{k=1}^{S} \beta_{i k} \delta_{k t}+u_{i t}
$$

where $R_{i t}$ and $E_{i t}$ are the actual and expected returns on stock $i$ respectively in period $t, \delta_{k t}$ is the $k$ th risk factor, $\beta_{k t}$ is the sensitivity of stock $i$ to the $k$ th factor, and $u_{i t}$ is a normally distributed error term with mean zero. By assuming no arbitrage opportunities the expected returns on stock $i$ becomes:

$$
E_{i t}=R_{F t}+\sum_{k=1}^{s} \lambda_{k} \beta_{i k}
$$

Where $R_{F t}$ is the risk free rate, and $\lambda_{k}$ is the risk premium associated with the $k$ th factor.

\section{Emerging Property Markets in the Middle East}

Global property investors are aware that the growth in the purchasing power of the domestic market is fantastic for the long-term profitability of all investments in the ME property markets (Akhtar, 2011). Therefore, generally, the future predictions for the property market in the ME countries are positive (IMF, 2012). Tables 2 and 3 present statistics for selected property markets and top fifty of PCs in the Middle East.

Table 2. Emerging property markets in the Middle East top of 50 PCs (all prices are in USD) December 2012

\begin{tabular}{lccccccc}
\hline Country & Ranging & $\begin{array}{c}\text { Number of } \\
\text { Companies }\end{array}$ & $\begin{array}{c}\text { Total } \\
\text { Market } \\
\text { Capital* }\end{array}$ & $\begin{array}{c}\text { Total Net } \\
\text { Profit }\end{array}$ & $\begin{array}{c}\text { Total } \\
\text { Assets }\end{array}$ & $\begin{array}{c}\text { Average } \\
\text { Share Price }\end{array}$ & $\begin{array}{c}\text { Average \% } \\
\text { Increase }\end{array}$ \\
\hline KSA & 1 & 19 & $64.51 \mathrm{~B}$ & $21.98 \mathrm{~B}$ & $71.41 \mathrm{~B}$ & 11.87 & 27.68 \\
UAE & 2 & 10 & $30.66 \mathrm{~B}$ & $28.42 \mathrm{~B}$ & $63.18 \mathrm{~B}$ & 0.75 & 33.42 \\
Qatar & 3 & 7 & $29.2 \mathrm{~B}$ & $9.69 \mathrm{~B}$ & $26.17 \mathrm{~B}$ & 10.73 & 11.68 \\
Kuwait & 4 & 6 & $22.19 \mathrm{~B}$ & $3.21 \mathrm{~B}$ & $45.55 \mathrm{~B}$ & 1.96 & 65.27 \\
Oman & 5 & 2 & $12.06 \mathrm{~B}$ & $1.029 \mathrm{~B}$ & $6.51 \mathrm{~B}$ & 2.51 & 58.27 \\
Jordan & 6 & 2 & $11.55 \mathrm{~B}$ & $0.812 \mathrm{~B}$ & $5.47 \mathrm{~B}$ & 8.53 & 17.05 \\
Syria & 7 & 1 & $4.08 \mathrm{~B}$ & $938 \mathrm{M}$ & $4.60 \mathrm{~B}$ & $\mathrm{~N} / \mathrm{A}$ & 6.90 \\
Lebanon & 8 & 1 & $2.43 \mathrm{~B}$ & $224.19 \mathrm{M}$ & $2.57 \mathrm{~B}$ & 19.70 & 19.11 \\
Bahrain & 9 & 1 & $3.24 \mathrm{~B}$ & $94.3 \mathrm{M}$ & N/A & N/A & 37.0 \\
Egypt & 10 & 1 & $1.98 \mathrm{~B}$ & N/A & N/A & 2.45 & 4.8 \\
Total & & 50 & & & & & \\
\hline
\end{tabular}

Source: Developed for this study. Arabian Business, (2012); CIA Fact (2011).

Market capital: Represents the aggregate value of company or a stock. It is obtained by multiplying the number of shares outstanding by their current price per share. 
Table 3. Top fifty PCs in the Middle East

\begin{tabular}{|c|c|c|c|c|c|c|c|}
\hline \# & Company & Country & $\begin{array}{l}\text { Market } \\
\text { Capital } \\
\end{array}$ & $\begin{array}{c}\text { Net } \\
\text { Profit }\end{array}$ & $\begin{array}{c}\text { Total } \\
\text { Assets } \\
\end{array}$ & $\begin{array}{l}\text { Share } \\
\text { Price }\end{array}$ & $\begin{array}{c}\% \\
\text { Increase } \\
\end{array}$ \\
\hline 1 & Emaar Properties - UAE & UAE & $6.52 \mathrm{~B}$ & $832.51 \mathrm{M}$ & $16.54 \mathrm{~B}$ & 1.07 & 73.89 \\
\hline 2 & Dar Al Arkan Real Estate Development & KSA & $4.95 \mathrm{~B}$ & $628.32 \mathrm{M}$ & $5.38 \mathrm{~B}$ & 6.88 & 15.44 \\
\hline 3 & Ezdan Real Estate & Qatar & $3.50 \mathrm{~B}$ & $373.12 \mathrm{M}$ & $1.90 \mathrm{~B}$ & 7.67 & 3.33 \\
\hline 4 & Jabal Omar Development & $\mathrm{KSA}$ & $3.46 \mathrm{~B}$ & $12.01 \mathrm{M}$ & $1.79 \mathrm{~B}$ & 5.15 & -4.93 \\
\hline 5 & ALDAR Properties & UAE & $3.37 \mathrm{~B}$ & $939.15 \mathrm{M}$ & $13.56 \mathrm{~B}$ & 1.31 & 23.08 \\
\hline 7 & Barwa Real Estate & Qatar & $2.88 \mathrm{~B}$ & $85.22 \mathrm{M}$ & $6.69 \mathrm{~B}$ & 10.97 & 31.68 \\
\hline 8 & Emaar The Economic City & $\mathrm{KSA}$ & $2.57 \mathrm{~B}$ & $77.87 \mathrm{M}$ & $2.54 \mathrm{~B}$ & 3.03 & 26.82 \\
\hline 9 & Sorouh Real Estate & UAE & $2.40 \mathrm{~B}$ & $506.31 \mathrm{M}$ & $4.62 \mathrm{~B}$ & 0.96 & 10.31 \\
\hline 10 & Arkan Building Materials & UAE & $2.39 \mathrm{~B}$ & $79.47 \mathrm{M}$ & $697.25 \mathrm{M}$ & 1.37 & -20.19 \\
\hline 11 & Southern Province Cement & KSA & $2.24 \mathrm{~B}$ & $210.95 \mathrm{M}$ & $732.97 \mathrm{M}$ & 16.00 & 28.76 \\
\hline 12 & Saudi Cement & $\mathrm{KSA}$ & $1.58 \mathrm{~B}$ & $165.68 \mathrm{M}$ & $1.21 \mathrm{~B}$ & 15.47 & 2.65 \\
\hline 13 & Yamama Saudi Cement & KSA & $1.41 \mathrm{~B}$ & $162.90 \mathrm{M}$ & $957.07 \mathrm{M}$ & 10.43 & 15.34 \\
\hline 14 & Yanbu Cement & KSA & $1.39 \mathrm{~B}$ & $149.26 \mathrm{M}$ & $693.27 \mathrm{M}$ & 13.20 & 26.92 \\
\hline 15 & Qassim Cement & $\mathrm{KSA}$ & $1.38 \mathrm{~B}$ & $137.79 \mathrm{M}$ & $605.38 \mathrm{M}$ & 30.67 & 42.41 \\
\hline 16 & Deyaar Development & UAE & $1.24 \mathrm{~B}$ & $112.31 \mathrm{M}$ & $3.07 \mathrm{~B}$ & 0.22 & 58.00 \\
\hline 17 & Mabanee & Kuwait & $1.23 \mathrm{~B}$ & $21.70 \mathrm{M}$ & $804.42 \mathrm{M}$ & 2.68 & 43.56 \\
\hline 18 & Makkah Construction \&Development & $\mathrm{KSA}$ & $1.22 \mathrm{~B}$ & $59.19 \mathrm{M}$ & $1.10 \mathrm{~B}$ & 7.41 & 18.80 \\
\hline 19 & Kuwait Cement & Kuwait & $1.21 \mathrm{~B}$ & $15.02 \mathrm{M}$ & $834.26 \mathrm{M}$ & 2.09 & 6.78 \\
\hline 20 & Mena Holding & Kuwait & $1.13 \mathrm{~B}$ & $92.37 \mathrm{M}$ & $983.20 \mathrm{M}$ & 1.88 & 211.54 \\
\hline 21 & Qatar National Cement & Qatar & $1.11 \mathrm{~B}$ & $113.73 \mathrm{M}$ & $784.48 \mathrm{M}$ & 24.77 & 12.96 \\
\hline 22 & Eastern Province Cement & $\mathrm{KSA}$ & $1.07 \mathrm{~B}$ & $115.79 \mathrm{M}$ & $586.80 \mathrm{M}$ & 12.48 & 17.0 \\
\hline 23 & Mohammad Al Mojil Group & $\mathrm{KSA}$ & $1.07 \mathrm{~B}$ & $152.11 \mathrm{M}$ & $978.30 \mathrm{M}$ & 8.53 & -9.30 \\
\hline 24 & United Development & Qatar & $1.06 \mathrm{~B}$ & $160.43 \mathrm{M}$ & $2.04 \mathrm{~B}$ & 9.93 & 2.27 \\
\hline 25 & Arabian Cement & KSA & $1.01 \mathrm{~B}$ & $86.44 \mathrm{M}$ & $977.32 \mathrm{M}$ & 12.64 & 52.41 \\
\hline 26 & IFA Hotels and Resorts & Kuwait & $1.01 \mathrm{~B}$ & $130.56 \mathrm{M}$ & $968.43 \mathrm{M}$ & 2.44 & 11.11 \\
\hline 27 & Qatar Shipping Company & Qatar & $998.08 \mathrm{M}$ & $142.39 \mathrm{M}$ & $1.50 \mathrm{~B}$ & 9.07 & -12.00 \\
\hline 28 & Arabtec Holding & UAE & $984.17 \mathrm{M}$ & $261.05 \mathrm{M}$ & $2.58 \mathrm{~B}$ & 0.82 & 33.63 \\
\hline 29 & Gulf Cable and Electrical Industries & Kuwait & $980.37 \mathrm{M}$ & $11.28 \mathrm{M}$ & $826.06 \mathrm{M}$ & 4.67 & 35.35 \\
\hline 30 & Union Properties & UAE & $948.59 \mathrm{M}$ & $207.93 \mathrm{M}$ & $5.24 \mathrm{~B}$ & 0.26 & 43.61 \\
\hline 31 & Saudi Real Estate & KSA & $860.78 \mathrm{M}$ & $31.21 \mathrm{M}$ & $846.46 \mathrm{M}$ & 7.17 & 36.55 \\
\hline 32 & Commercial Bank International & UAE & $784.85 \mathrm{M}$ & $35.23 \mathrm{M}$ & $3.06 \mathrm{~B}$ & 0.63 & 49.15 \\
\hline 33 & The Commercial Real Estate & Kuwait & $781.23 \mathrm{M}$ & $50.41 \mathrm{M}$ & $1.39 \mathrm{~B}$ & 0.45 & 2.28 \\
\hline 34 & Saudi Arabian Amiantit & KSA & $756.12 \mathrm{M}$ & $62.75 \mathrm{M}$ & $1.20 \mathrm{~B}$ & 6.55 & 39.49 \\
\hline 35 & Saudi Ceramics & KSA & $743.31 \mathrm{M}$ & $47.44 \mathrm{M}$ & $417.25 \mathrm{M}$ & 29.73 & 4.69 \\
\hline 36 & Taiba Holding Company & $\mathrm{KSA}$ & $729.98 \mathrm{M}$ & $42.71 \mathrm{M}$ & $954.73 \mathrm{M}$ & 4.87 & 3.40 \\
\hline 37 & Raysut Cement & Oman & $702.91 \mathrm{M}$ & $70.41 \mathrm{M}$ & $305.59 \mathrm{M}$ & 3.51 & 22.67 \\
\hline 38 & Qatar Real Estate Investment & Qatar & $650.91 \mathrm{M}$ & $85.63 \mathrm{M}$ & $1.60 \mathrm{~B}$ & 7.53 & -5.8 \\
\hline 39 & Jordan Cement Factories & Jordan & $646.21 \mathrm{M}$ & $69.80 \mathrm{M}$ & $403.05 \mathrm{M}$ & 10.69 & 17.05 \\
\hline 40 & Saudi Cable & $\mathrm{KSA}$ & $624.20 \mathrm{M}$ & $56.55 \mathrm{M}$ & $911.88 \mathrm{M}$ & 8.21 & 16.23 \\
\hline 41 & Saudi Hotels and Resort Areas & $\mathrm{KSA}$ & $585.16 \mathrm{M}$ & $32.80 \mathrm{M}$ & $520.66 \mathrm{M}$ & 8.48 & 39.1 \\
\hline 42 & Red Sea Housing Services & KSA & $559.99 \mathrm{M}$ & $57.07 \mathrm{M}$ & $267.48 \mathrm{M}$ & 18.67 & -6.35 \\
\hline
\end{tabular}




\begin{tabular}{|c|c|c|c|c|c|c|c|}
\hline 43 & Drake and Scull International & UAE & $539.99 \mathrm{M}$ & $27.24 \mathrm{M}$ & $261.21 \mathrm{M}$ & 0.25 & 22.97 \\
\hline 44 & Ahli United Bank - Investment Funds & Bahrain & $243 \mathrm{M}$ & $94.3 \mathrm{M}$ & N/A & N/A & 37 \\
\hline 45 & Gulf Cement & UAE & $525.77 \mathrm{M}$ & $0.58 \mathrm{M}$ & $493.36 \mathrm{M}$ & 0.64 & 3.98 \\
\hline 46 & Afaq for Investment and RE Develop & Jordan & $509.77 \mathrm{M}$ & $11.40 \mathrm{M}$ & $144.10 \mathrm{M}$ & 6.37 & 0.00 \\
\hline 47 & Oman Cement & Oman & $503.65 \mathrm{M}$ & $32.57 \mathrm{M}$ & $345.45 \mathrm{M}$ & 1.52 & 94.68 \\
\hline 48 & Gulf Holding Company & Qatar & $415.73 \mathrm{M}$ & $9.38 \mathrm{M}$ & $460.48 \mathrm{M}$ & 5.20 & 8.62 \\
\hline 49 & Gulf Holding Company-Syria Projects & Qatar & $408.84 \mathrm{M}$ & $9.38 \mathrm{M}$ & $460.15 \mathrm{M}$ & N/A & 6.90 \\
\hline 50 & Egyptian Real Estate Group & Egypt & $198.01 \mathrm{M}$ & N/A & N/A & 2.45 & 4.8 \\
\hline
\end{tabular}

Sources: Developed for this study - Local Stock Exchange Markets; IMF (2012) ; AMF (2012).

\section{Markowitz Model}

The efficiency of portfolios has been a topic for debate over the last twenty years within the body of finance literature. Depending on time periods analysed and types of assets invested in, the answer to efficiency varies. However, the implications for investment opportunity abound if it can be demonstrated that funds either are or are not efficiently priced assets. If individual assets are less than efficiently priced then a strategy application of efficiently selecting these assets using modern portfolio and Minimum Mean-Variance Portfolio (MVP) analysis would tend to be financially rewarding (Wu, 2008).

\subsection{Analysis of the Results}

When analysing the calculated expected returns and standard deviations it can be observed that QRES has the highest expected return (1.96\%) followed by ABYAAR (1.86\%) and SRECO (1.2\%). Their respective standard deviations are $6.32 \%, 7.1 \%$ and $5.04 \%$. It can be presumed that these stocks will have a large weight in the high return portfolios, because compared to the other PC stock returns these are the most profitable. In building portfolios correlation coefficients negative ones, allow for effective risk diversification. However, QRES, ABYAAR and SRECO will probably constitute a relatively low weight in the low risk portfolios, due to their high standard deviations, but here again the correlation coefficients must be taken into account. A stock with high volatility of returns can be included in a low risk portfolio if its correlation with the stocks in the portfolio is low. On the other hand, DEYR has a negative expected return $(-0.32 \%)$ and a relatively high standard deviation $(6.33 \%)$. As it has a negative expected return it is highly unlikely it is going to be included in the high-return portfolios, but its correlation will determine it's in the low risk portfolios.

\subsection{Analysis without Short Selling}

The MVP strategy (Trust) seeks to maximize total return primarily through capital appreciation and dividend income. In this study the global MVP consists of nine PCs stocks. AREG is the only stock that is not included in the Global MVP. This can be explained by its high risk to expected return ratio and high correlation compared with the other stocks. Although ARED and KRE have lower expected returns $(0.58 \%$ and $0.1 \%$ respectively) and approximately the same level of standard deviations, their weight allocation in the portfolios is larger than of AREG. This is due to the individual correlation of stocks. SRECO has the highest weight in the MVP (22.04\%). However since it has a relatively low expected return $(0.1 \%)$ its weight decreases as higher expected return portfolios are selected. It can also be observed that QRES has the highest expected return (1.96\%) followed by ABYYAR (1.86\%). These securities have a large weight in the high return portfolios, because of their high expected returns.

\subsection{Analysis with Short Selling}

Short selling is known as the selling of stocks that are not in the possession of the investor at the time of sale. The investor is hence selling a stock that is borrowed from someone else with intent of repurchasing it at a later date and returning it to the lender of the stock (Haugen, 1997). In real life, very few investors have the opportunity if unrestricted short selling. The global minimum variance portfolios are similar in the cases of short selling and no short selling in the sense that AREG is not included (1.38\% sold short). The reason why the stock is short sold is the same why it was excluded from the MVP with no short selling; the combination of its expected return, standard deviation and its correlation coefficients. As portfolios with higher returns are analysed the pattern is that ARED, KRE, DEYR, and SOROUH are being short sold at an increasing rate while the rest of the stocks of the portfolio constitute higher weights. The reason for this is DEYR has a negative expected return $(-0.32 \%)$, whish increases the overall expected return of the portfolio. In portfolio 1, which has the highest 
expected return (9.88\%), EMAR and QRES have the highest weights of $228.43 \%$ and $131.05 \%$ respectively. This is mainly due to KRE and DEYR being heavily short sold (324.13\% and $250.67 \%$ respectively). ARED and SOROUH are also short sold (74.15\% and 33.31\% respectively). The extent to which KRE and DEYR are short sold can pose a problem as short selling induces risk, because if the price of the stock that is short sold is rising while the prices of the other stocks in the portfolio are falling the investor is losing at both ends. However, if the price of the short sold stock is falling it is profitable because the stock will be bought back at a lower price that it was purchased. Short selling can therefore be the case of "feast or famine" as it can be very profitable, but at the same very risky. Also, as the correlation coefficients are mainly positive, investors will prosper from one position, but suffer from the other.

\section{Single Index Model (SIM)}

The single index model implicitly assumes that two types of events produce variability in a stock's rate of return. We refer to the first type of event as a macro event. These events affect nearly all firms to a certain degree and may affect the general level of stock prices. They cause a change in the rate of return to the market portfolio, which dye to the pull of the market changes the rates of return on individual stocks. Micro events on the other hand influence specific firms with little impact on other stocks. The single index model is essentially used to estimate the betas of various stocks, which give the measure of the risk of shares. The beta factor of the stock is an indicator of the degree to which the stock responds to changes in the return produced be the market. If the market portfolio is efficient than a perfect linear relationship should exist between the beta factor of stocks and their expected rates of return.

\subsection{Analysis with Short Selling}

Considering Short Selling in the Single Index Model, stocks that have low return and comparatively higher risks than other stocks are short sold in order to take advantage of their "under-performance". Table 4 illustrates the analysis stocks with decreasing weights in the portfolios.

Table 4. Stocks with decreasing weight in portfolios on the efficient frontier

\begin{tabular}{ccccc}
\hline Stock & Risk (SD) & Volatility (BETA) & Expected Return & Risk/Return \\
\hline ARED & 4.57692 & 0.99395 & 0.59203 & 7.730892016 \\
KRE & 4.10774 & 0.81341 & 0.09827 & 41.80054951 \\
DEYR & 6.32993 & 0.92908 & -0.31633 & -20.01052698 \\
\hline
\end{tabular}

The contribution of ARED, KRE and DEYR in portfolios along the efficient frontier is reduced because higher expected return is required. These stocks were short sold in order to allocate more funds in other stocks, which had higher expected return. Consider Table 5 where all the other stocks are analysed.

Table 5. Stocks with increasing weight in portfolios on the efficient frontier

\begin{tabular}{ccccc}
\hline Stock & Risk (SD) & BETA & Expected Return & Risk/Return \\
\hline AREG & 4.68706 & 1.22562 & 0.92802 & 5.050602358 \\
QRES & 6.315 & 0.74227 & 1.95641 & 3.227851013 \\
ABYAAR & 7.0857 & 0.9297 & 1.91685 & 3.3696533375 \\
BRES & 4.60249 & 0.7908 & 0.87675 & 5.249489592 \\
SRECO & 4.94321 & 0.97381 & 1.29475 & 3.817887623 \\
EMAR & 5.80332 & 0.97369 & 0.947 & 6.12810982 \\
SOROUH & 11.5492 & 1.01082 & 1.00292 & 11.51557452 \\
\hline
\end{tabular}

Analysing the above table it can be seen that the risk to return ratio in the stocks is better than the stocks continuously sold short in the portfolios. SOROUH, EMAR, ABYAAR, and AREG returns are comparatively higher than the stock short sold in the portfolios. It can also be observed that as we move along the efficient frontier the weight of short selling stocks decreases and weight in other the stocks increases. The highest 
allocations were made in QRES, ABYAAR and SRECO. Although QRES has a high risk-return ratio, the low beta value justifies the stability compared to the other stocks in the portfolio. Similarly, ABYAAR and SRECO both have a higher risk to return ratio but the weight allocated increase due to their low betas.

\subsection{Analysis without Short Selling}

In the case of no-short selling the possible selection of stocks becomes limited. The performance of various stocks in the portfolio is divided into following three tables. The stocks with increasing weight, the stocks with decreasing weight and the varying weight stocks. Table 6 includes stocks for which the weights increase as we move along the efficient frontier.

Table 6. Stocks with increasing weight in portfolios along the efficient frontier

\begin{tabular}{ccccc}
\hline Stock & Risk (SD) & BETA & Expected Return & Risk/Return \\
\hline QRES & 6.315 & 0.74227 & 1.95641 & 3.227851013 \\
ABYAAR & 7.0857 & 0.9297 & 1.91685 & 3.696533375 \\
EMAR & 5.80332 & 0.97369 & 0.947 & 6.12810982 \\
\hline
\end{tabular}

The above table illustrates the stocks that have high weight allocation in the portfolios along the efficient frontier because of their expected return, risk-return ratio and correlation with respect to the market index. QRES has a comparatively lower risk-return trade off ratio and the lowest correlation to the market. That is the reason why it is heavily invested in various portfolios followed by ABYAAR and EMAR. The undiversified portfolio consists of QRES based on its high expected return as compared to other stocks. Table 7 presents the stocks with varying weight in portfolios along the efficient frontier.

Table 7. Stocks with varying weight in portfolios along the efficient frontier

\begin{tabular}{ccccc}
\hline Stock & Risk (SD) & Volatility (BETA) & Expected Return & Risk/Return \\
\hline AREG & 4.68706 & 1.22562 & 0.92802 & 5.050602358 \\
BRES & 4.60249 & 0.7908 & 0.87675 & 5.249489592 \\
EMAR & 5.80332 & 0.97369 & 0.947 & 6.12810982 \\
SOROUH & 11.5492 & 1.01082 & 1.00292 & 11.51557452 \\
\hline
\end{tabular}

All of the stocks considered in this category had varied in weight in the efficient set. As we move along the efficient frontier the proportion invested in these stocks rises and then falls as we move closer to the undiversified portfolio. Table 8 shows the stocks with falling weights in the portfolios. As we move along the efficient frontier ARED, KRE and DEYR were eliminated because of their higher risk-return ratio and higher betas.

Table 8. Stocks with falling weight in portfolio along the efficient frontier

\begin{tabular}{ccccc}
\hline Stock & Risk (SD) & BETA & Expected Return & Risk/Return \\
\hline ARED & 4.57692 & 0.99395 & 0.59203 & 7.730892016 \\
KRE & 4.10774 & 0.81341 & 0.09827 & 41.80054951 \\
DEYR & 6.32993 & 0.92908 & -0.31633 & -20.01052698 \\
\hline
\end{tabular}

\section{Drawbacks of the Single Index Model}

The Single Index Model in addition to the drawbacks of the Markowitz Model possesses additional limitations. The variance obtained in only an approximation of the true variance, because it assumes the residuals are uncorrelated across different companies. 


\subsection{Analysis of the Sub-Samples}

The Markowitz and the Single Index Models compute the efficient set by estimating the expected return and covariance between the securities in the available population of stocks. In this paper these estimates were calculated by sampling from past returns. Whilst this is the most straightforward approach, its drawback is that the sample means of stock returns are unstable and unreliable as estimates of true rate of return. Sampling error can be reduced by estimating a lengthy history of past returns, however, the future return series of a company are significantly different from its past. The past returns of a company do not reflect the contemporary character of the company as disregard the current macro and micro events affecting the company. In order to provide better estimates of covariance expected returns and portfolio volatility, the data provided was spilt in two subgroups. Each subgroup comprised of 33 observations, with one set reflecting the data from Jan 2007 to Sept 2009 and the second set reflecting the data from Oct 2009 to June 2012, which will be referred to in the report as subgroup 1 and subgroup 2. Splitting the data into two sets of years provides a better estimation of the efficient frontiers and betas, which allows for a comparison between the portfolios in different subgroups.

\subsection{Analysis without Short Selling}

The global MVP of international portfolio for subgroup 1 has an expected return of $1.08 \%$ and a standard deviation of $2.80 \%$ and comprises of AREG (12.73\%), QRES (14.89\%), ABYAAR (13.98\%), BRES (17.7\%), SRECO (9.66\%) and SOROUH (4.44\%). The MVP for subgroup 2 has an expected return of 1.1575, standard deviation of 2.1126 and comprises of ARED (26.64\%), QRES (12.66\%), KRE (16.47\%), BRES (5.14\%), SRECO $(21.10 \%)$ and EMAR (17.99\%). It can be noticed that expected return and standard deviation for the higher expected return portfolios the differences between the expected returns and standard deviation of the portfolios between subgroup 1 and 2 become larger. This reiterates the belief that large samples of historical data do not reflect the current character of the company. Furthermore, the share composition of the global MVP for subgroup 1 is quite different from subgroup 2. For instance, AREG is included in the efficient frontier calculated in subgroup 1, but is excluded from the efficient portfolios in subgroup 2. Similarly ARED does not feature in the portfolios of subgroup 1 but in subgroup 2, which it is proposed that ARED should constitute $26.64 \%$ of the Global MVP. It is also interesting to note that in subgroup 1 ABYAAR is considered to provide the highest return with the highest risk whereas in subgroup 2 QRES is considered to be most efficient in an undiversified portfolio. This indicates that the expected rates of return for stocks vary according to the time span and their volatility changes significantly. In addition it is evident that neither one of the subgroups dominates the results obtained by evaluating 66 observations from Jan 2007 to June 2012, however they are an approximation of the results of the two subgroups. For instance, in most of the portfolios with the 3 years time span, AREG has no weight allocation. In the global MVP all stocks are included except for AREG with maximum weights being allocated to KRE and BRES. As we move along the efficient frontier the portfolios become less diversified, which leads to QRES and ABYAAR dominating the portfolios. This is quite similar to the results of the two subgroups as the portfolios in subgroup 1 had a large concentration in ABYYAR and the portfolios in subgroup 2 were weighted heavily in QRES. However, it is important to note that the weights being allocated to different stocks in the various portfolios of the main group and its two subgroups varied which can be attributed to the different expected returns and standard deviations of individual portfolios over different lengths of time.

\subsection{Markowitz Model with Short Selling}

In subgroup 1 the stock composition in the Global MVP is significantly different from that of subgroup 2, which is also true for all the other portfolios included in the two subgroups. In subgroup $1 \mathrm{KRE}$, ARED, DEYR and BRES are being sold short because of the negative or very low expected return. As we move along the efficient frontier the short selling in these stocks tends to become more extensive, which is apparent in the case of KRE due to its negative expected return. Furthermore, AREG has the highest weight in all the portfolios followed by ABYAAR which is, primarily due to the return these stocks offer in comparison to the level of risk involved. In subgroup 2 ARED, DEYR, KRE, and SOROUH are being sold short and a long position is taken in all other stocks with maximum weights being sold short and a long position is taken in all other stocks with maximum weights being allocated to BRES and EMAR. With regards to short selling both the subgroups have almost the same stocks, but their weights within the portfolios differ substantially, which is due to the varied correlation between stocks. In subgroup 1, ARED and EMAR are being short and long positions are being taken in all other stocks. On the other hand, in subgroup 2 AREG, DEYR and SOROUH are being sold short and long positions are taken in all the other stocks. This indicates that the risk and return estimates are not stable over long periods of time. However, evaluating results on the basic of limited data leads to imprecise estimates. The results obtained from 66 observations were an approximation of the results of the two subgroups as the concentration on short selling was on the same stocks namely: KRE, DEYR, ARED and SOROUH. However, the expected returns 
on individual stock were considerably different from those achieved by splitting the data into two subgroups, which affected the weight allocation of the individual stocks within different portfolios. In addition, the correlation coefficients of the stocks between the subgroups and the main observation varied significantly.

\subsection{Single Index Model with and without Short Selling}

In the single index model the betas for the efficient set are the same for estimates calculated with or without short selling. However, they do not remain constant if the data is split into two subgroups. In the case of subgroup 1 ARED, SRECO, AREG and EMAR have betas above 1 whereas in subgroup 2 this is the case for AREG, DEYR, ABYAAR and SOROUH. This indicates that the betas for individual stock vary significantly with the time span used. Furthermore it is noted that while calculating the Single Index Model with 66 observations, the betas of AREG and SOROUH were over 1 and most of the other stocks had betas between 0.7 and 0.9. Since betas provide the estimation of risks of the stock, the inconsistency of the betas reflects the volatility of the stocks with the amount of data available and the time period over which the returns were calculated. In subgroups 1 and 2 with short selling, the expected returns in individual stock vary significantly. For instance, in subgroup 1 SOROUH has an expected return of 3.01\% whereas, in subgroup 2 it's expected return is $-1.00 \%$. Whilst comparing this with the results from 66 observations, the expected return of SOROUH is $1.002 \%$, this indicates the variability in returns caused by changing the size of the samples.

\subsection{Analysis of the Sub-Samples}

It is important to be aware of the drawbacks of the Markowitz model. Firstly, the calculations are based on historical data, which is not necessarily a good indicator of future prices. The analysis only shows the portfolios that would have been efficient during the period studied, but this does not necessarily indicate the efficient frontier for the future. Secondly, the calculations are subject to estimation risk, because the parameters used are estimates, not population values. Sample means of stock returns are unstable and unreliable as estimates of the true rate of return. In order to reduce sampling error, sample estimates also require a lengthy history of past returns. Unfortunately the further back of the data is recorded the more likely the chance that the series of stock returns doesn't reflect the contemporary character of the PCs. This can cause distortions in the results, because the efficient frontier is sensitive to the errors in these estimates. Thirdly, stocks returns are asymmetrically distributed, whereas the Markowitz model assumes normal distribution of returns with zero mean.

\section{Conclusions and Recommendations}

The analysis of the results clearly indicated the significance of selecting an appropriate time span for the historical stocks returns used for calculating the efficient frontier. It was shown in this paper that the estimated parameters of the models differ considerably when different time frames are chosen for the analysis. In addition the number of observations used for the calculations has great ramifications on the accuracy of the estimates. As long time spans do not reflect the current character of stocks it becomes important to keep the intervals between observations as narrow as possible. The efficient frontiers for both models were analysed and justifications for the inclusion and exclusion of certain stocks were discussed. This provided valuable insight into the importance of correlation between PCs' stocks in risk diversification. However, the presented approach has a number of limitations. The main weakness of the Markowitz model is that it selects the portfolios of stocks that were efficient in the period under observation. This does not necessarily provide investors with reliable forecast of the future. While makes the decision on the selection of an investment portfolio, the fundamental of stocks should be considered along with their past returns and volatilities. A way of incorporating the fundamental methodology with the Markowitz model is to use "classes" of commodities instead of single stocks in the calculations. An example of classes should be: (1) The common stocks of large property companies, (2) The common stocks of small property companies, (3) Venture capital investments, (4) Foreign common stocks, (5) Domestic fixed interest investments, (6) Foreign fixed interest investments, (7) Real estate investments, (8) Money market investments. In this approach the estimates of the expected return on each class of investments are based on historical of return of that class. The covariance matrix is estimated on the basis of sample estimates taken from historical returns associated with portfolios of securities in each investment class. This modified approach has the advantages of allowing the choice of securities that seem to presses sound fundamentals, but on the other hand are included in a class of investments that is part of the efficient frontier. A similar approach can also be used with index models. One of the weaknesses of the SIM is that the estimate of beta is based only on the stock's past relationship with the market, but doesn't take into account the characteristics of the company behind the stock. The use of "a fundamental" beta helps to overcome that obstacle. Fundamental beta takes into consideration numerous factors, such as variability in earnings per share (EPS), company size and financial leverage and relates these factors to company betas in the past to find the relationship between them. Although 
the models are imperative in the selection of the efficient portfolios fundamentals of stocks remain the main determinant for portfolio selection. Thus, the past return and volatility alone should not be the only factors influencing investor's decisions. Certainly, it is important to note that the outcome of this paper is specific to the PCs stocks that were included in each portfolio and during the period in which this paper was conducted. Due to changing economic conditions in the Middle East between 2011 until now and throughout the world, the results may be different for future portfolios. In addition, as Real Estate market becomes more volatile, such results may not hold due to greater imbalances and global market inefficiency. Future studies need to re-examine the current paper purpose and repeat this work to confirm the consistency of this results over a longer time period. Additionally, I believe that there are many reputable Middle Eastern PCs listing can be included in future research. Thus, future studies need to include these companies in their portfolios.

\section{References}

A Year of Revival for Property Sector. (2010). Visit Kuwait. Retrieved from http://www.visit-kuwait.com/property/513-2009-Year-of-revival-for-Kuwait-property-sector.htm

Akhtar, S. (2011). Emerging developments and challenges in the Arab World. Arab World Brief, February.

Al-Karasneh, A., \& Fatheldin, M. (2005). Market structure and performance in the GCC banking sector evidence from Kuwait, Saudi Arabia and UAE. Arab Monetary Fund, 4, 391-414. Retrieved January 10, 2013, from http://www.wto.org

Alkulaiba, Y., Najandb, M., \& Mashayekhc, A. (2009). Dynamic linkages among equity markets in the Middle East and North African countries. Journal of Multinational Financial Management, 19(1), 43-53. http://dx.doi.org/10.1016/j.mulfin.2008.03.002

Arab Monetary Fund. (2012). Articles and publications. Retrieved February 15, 2013, from http://www.wto.org

Arabian Business. (2012). Real estate statistic and issues. Retrieved March 1, 2013, from www.arabianbusiness.com

Barwa Real Estate. (2010). Arabian business. Retrieved from http://www.arabianbusiness.com/financial-markets/companies/511/profile

Business Monitor International. (2011). United Arab Emirates autos report Q1 2011. The Middle East Journal, 65(1), 85-102.

Cho, D., Chinhyung, E., Cheol, S., \& Senbet, W. (1986). International arbitrage pricing theory: An empirical investigation. Journal of Finance, 41, 313-329. http://dx.doi.org/10.1111/j.1540-6261.1986.tb05038.x

CIA Fact Book. (2010). Statistics and various issues.

CIA Fact Book. (2012). Statistics and various issues.

Dubai Property Companies Called Merger Off. (2009). Property Wire. Retrieved from http://www.propertywire.com/news/middle-east/dubai-property-companies-merger-called-off-2009121037 47.html

Egypt Property. (2010). Select property. Retrieved from http://www.selectproperty.com/research-articles/Egypt-property-market/Egyptian-real-estate-market

Egypt Real Estate Attracts Interest From Foreign Investors. (2010). New investors. Retrieved from http://www.nuwireinvestor.com/egypt-estate-attracts-strong-interest-from-foreign-investors-56196.aspx

Emaar Properties UAE. (2010). Arabian Business. Retrieved from http://www.arabianbusiness.com/financial-markets/companies/41/profile

Errunza, V., Losq, E., \& Padmanabhan, P. (1992). Test of integration, mild segmentation and segmentation $\begin{array}{llll}\text { hypotheses. Journal of Banking and Finance, 16, 949-972. } & \text {. }\end{array}$ http://dx.doi.org/10.1016/0378-4266(92)90034-W

Finkelstein, A. (2010). Kuwait real estate markets, world property channel. Retrieved from http://www.worldpropertychannel.com/international-markets/commercial-real-estate/real-estate-news-kuwa it-real-estate-market-martin-cooper-dtz-real-estate-advisor-martin-cooper-2608.php 
Frino, A., Cusack, T., \& Wilson, K. (2001). Introduction to corporate finance. Australia: Pearson Education Australia.

Haugen, R. (1997). Modern investment theory. Prentice Hall.

International Monetary Fund. (2011). IMF Backs G-8 Plan for Supporting Middle East, North Africa, May 27.

International Monetary Fund. (2011). Regional Outlook.

International Monetary Fund. (2011). World economic outlook.

International Monetary Fund. (2012). World economic outlook.

Lintner, J. (1965). The valuation of risk assets and the selection of risky investments in stocks portfolios and capital budgets. Review of Economics and Statistics, 47, 13-37. http://dx.doi.org/10.2307/1924119

Marashdeh, H. (2007). Are the stock markets in the Middle East region efficient? International Review of Business Research Papers, 3(5), 297-307.

Morgan Stanley Capital International. (2011). Retrieved March 10, 2013, from http://www.msci.com

Mosin, J. (1966). Equilibrium in a capital asset market. Econometrica, 34, 768-783. http://dx.doi.org/10.2307/1910098

Qatar Real Estate. (2010). Century 21. Retrieved from http://www.century21qatar.com/images/stories/MarketReports/qr2-2010_en.pdf

Sharpe, W. (1964). Capital asset prices: A theory of market equilibrium under conditions of risk. Journal of Finance, 19, 763-781.

$\mathrm{Wu}$, J. (2008). The portfolio decision under the VAR. Asian Social Science, 4(2), 58-64. Retrieved from http://ccsenet.org/journal/index.ass/article/viewFile/2008/1904

\section{Copyrights}

Copyright for this article is retained by the author(s), with first publication rights granted to the journal.

This is an open-access article distributed under the terms and conditions of the Creative Commons Attribution license (http://creativecommons.org/licenses/by/3.0/). 